\section{David Jack (1924-2011) who revolutionised the treatment of asthma}

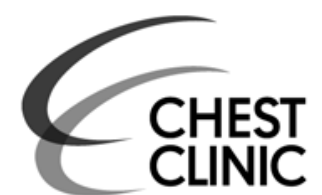

Sir David Jack FRS, former Director of Research and Development at Glaxo, died on 8 November 2011 at the age of 87 years. He probably did more to benefit patients with asthma and chronic obstructive pulmonary disease than anyone else in history. He discovered the first $\beta_{2}$-selective agonist (salbutamol), the first inhaled corticosteroid (beclomethasone dipropionate), the first long-acting $\beta_{2}$-agonist (salmeterol), the most widely used inhaled corticosteroid (fluticasone propionate) and the best-selling asthma treatment of all time (Seretide). He also discovered several other important drugs, including the histamine $\mathrm{H}_{2}$-receptor antagonist ranitidine (Zantac), which became the best-selling drug of its day, and sumatriptan (Imigran), a novel therapy for migraine.

David Jack was born in Markinch, Fife, the sixth and youngest child of a coal miner. It is extraordinary that the other great drug discoverer of our time, Sir James Black, who went on to discover $\beta$-blockers and histamine $\mathrm{H}_{2}$-receptor antagonists, was born in the same year in a nearby village. James Black was awarded the Nobel Prize for Medicine in 1988, and many think that David

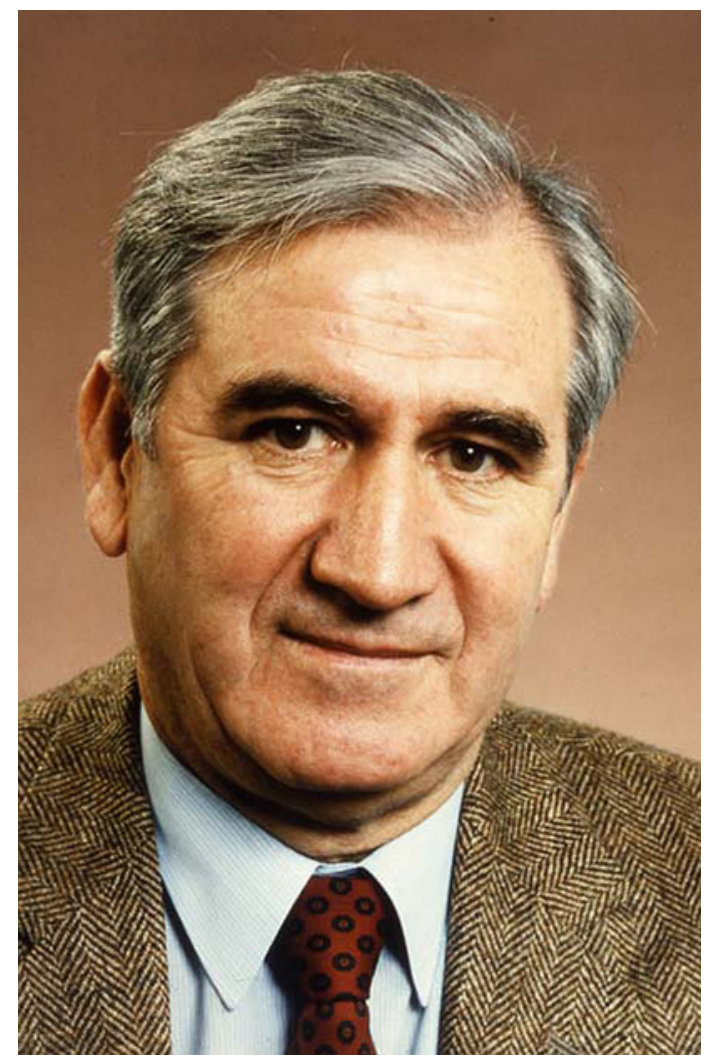

Sir David Jack born 22 February 1924, died 8 November 2011
Jack should also have been similarly honoured. After secondary education at Buckhaven High School, David became an apprentice pharmacist with Boots the Chemists in Cupar, turning down an opportunity to study mathematics at the Edinburgh University, as his intention was to become a retail pharmacist. In 1944, he entered a BSc course in Chemistry and Pharmacy at the Royal Technical College in Glasgow (now Strathclyde University), where he won every undergraduate prize open to him and graduated with first class honours. He then became an Assistant Lecturer in Experimental Pharmacology in the University of Glasgow having turned down an offer to study for a $\mathrm{PhD}$. He joined Glaxo Laboratories in 1951 as a pharmacist where his main role was to formulate new products and supervise their transfer to production. But he found this work repetitive and unfulfilling and in 1953 moved to Smith Kline \& French as Senior Development Pharmacist, while at the same time studying for an external $\mathrm{PhD}$ at the Chelsea College of Technology under the supervision of Professor Arnold Beckett. His exceptional research potential was immediately recognised and in 1961 he was invited to become Director of Research and Development at Allen and Hanburys, whose parent company was Glaxo. At this time, Allen and Hanburys were best known for their blackcurrant pastilles! At the Ware research laboratories he brought together a remarkably productive team of chemists, pharmacologists and pharmacists in order to achieve his ambition of inventing medicines to treat important human diseases, a venture new to Glaxo group that time.

David Jack is best known for the discovery of some of the most effective and widely used drugs to treat asthma and chronic obstructive pulmonary disease. He appreciated the importance of delivering asthma treatments directly to the lungs by inhalation to produce a more rapid effect and to have fewer systemic side effects than drugs given by mouth. Working with Roy Brittain, he recognised the advantage of developing selective activators of $\beta_{2}$-receptors to avoid cardiovascular side effects from stimulating $\beta_{1}$-receptors that were seen with the nonselective inhaled $\beta$-agonist isoprenaline. This led to the discovery of salbutamol (Ventolin), the first selective $\beta_{2}$-receptor agonist, which was launched in 1969. This proved to be a major commercial success and remains the most widely used asthma drug in the world today. But its duration of action is relatively short and patients had to use it frequently. This led David and his team to develop the first long-acting $\beta_{2}$-receptor agonist, salmeterol, which has a duration of action of over $12 \mathrm{~h}$. Salmeterol was discovered by careful structure-function studies to optimise the duration of action by prolonging the time the drug occupies the $\beta_{2}$-receptor and was launched in 1990. Oral corticosteroids were very effective in asthma treatment but could not be used routinely because of many long-term side effects and previous attempts to give steroids, such as hydrocortisone, by nebulisation had failed. Allen and Hanburys had already developed a steroid skin cream and it was argued that similar topical steroids could be effective by inhalation and thereby avoid systemic side effects. This led Jack's team to develop the first inhaled corticosteroid beclomethasone dipropionate (Becotide), which was launched in 1972. Inhaled steroids have revolutionised the therapy of asthma, cutting down asthma exacerbations, preventing hospital admissions and reducing mortality. Jack's team then went on to develop fluticasone propionate, 
which is more potent than beclomethasone dipropionate and has reduced oral bioavailability. This has now become the most widely used corticosteroid in the world. Clinical studies showed that when salmeterol was added to fluticasone propionate it improved asthma control to a greater extent than increasing the dose of inhaled corticosteroids and this led to the logical development of a combination inhaler (Seretide) which was launched in 2000 and went on the become the third best selling drug in the world.

But David Jack also discovered important drugs for other common diseases. His friend James Black had invented the first effective treatment for peptic ulcer, cimetidine (Tagamet), which acted by blocking histamine receptors in the stomach. Using logical chemical approaches David improved on cimetidine to develop ranitidine (Zantac) in 1981, which had a longer duration of action and fewer side effects and was to become the biggest selling drug in the world and the first blockbuster drug to make over $\$ 1$ billion a year. Other discoveries followed from work with Pat Humphrey on drugs which bound to newly discovered serotonin receptors. This produced the $5-\mathrm{HT}_{1 \mathrm{~B}}$ and $5 \mathrm{HT}_{1 \mathrm{D}}$-receptor agonist sumatriptan (Imigran) for the treatment of migraine, the $5 \mathrm{HT}_{3}$-receptor antagonist ondansetron (Zofran) for the treatment of nausea following chemotherapy, both launched in 1991. This succession of drug discoveries was largely responsible for making Glaxo one of the most successful pharmaceutical companies in the world and one of the greatest business successes in the UK. Since his official retirement from Glaxo in 1987, David continued to act as a consultant for them and for a drug development company Verona, where he was working on inhaled phosphodiesterase 3/4 inhibitors for asthma.

Not surprisingly, many honours came his way. He was awarded a CBE in 1982 and knighted in 1993 for his services to the British pharmaceutical industry. He was elected a Fellow of the Royal Society of Edinburgh in 1978 and elected FRS in 1992. He was awarded the Royal Society's Mullard Medal in the same year. The British Pharmacological Society, the Royal Pharmaceutical Society and the Royal Society of Chemistry all bestowed their highest awards and he was given honorary degrees by seven universities.

David Jack was passionate about science and was the catalyst for the work of many others both in industry and in academia. His logical approach to drug development, and to solving the difficult problems of invention, has been the inspiration to a generation of basic and clinical scientists and is sadly often missing today. He retained his enthusiasm for science and pharmacology into retirement. He showed great kindness especially to junior colleagues who remember him with great affection as well as enormous respect. The high standards that he espoused and his unwillingness to accept anything less have left an indelible mark and we are unlikely to see anyone with his ability for drug discovery again.

In all this, David was ably supported by a strong and stable family life. Lydia was a fellow pharmacy student in Glasgow, and they married in 1952. She gave him the support he needed when negotiating the caprices of the pharmaceutical industry and survives him with their two daughters. His hobbies included gardening, golf and theatre-going. Many will mourn his passing. Doctors and patients with common diseases throughout the world and particularly those with obstructive airway diseases owe him an enormous debt of gratitude as his research has literally transformed their lives.

\section{Peter J Barnes, ${ }^{1}$ Alastair Breckenridge ${ }^{2}$}

${ }^{1}$ National Heart \& Lung Institute, Imperial College, London, UK; ${ }^{2}$ MHRA, London, UK

Correspondence to Professor Peter Barnes, National Heart \& Lung Institute, Dovehouse Street, London SW3 6LY, UK; p.j.barnes@imperial.ac.uk

Competing interests None.

Contributors Both authors contributed to this obituary.

Provenance and peer review Commissioned; internally peer reviewed.

Published Online First 16 January 2012

Thorax 2012;67:266-267. doi:10.1136/thoraxjnl-2011-201522 